\title{
PEMANTAPAN DAN PENGUKUHAN PENGAJIAN FIQH SYAFI'I DI INSTITUSI PENGAJIAN TINGGI : SATU PENILAIAN, PEMERHATIAN TULUS DAN PENGALAMAN
}

Oleh:

Rushdi Bin Ramli*

\begin{abstract}
This article is intended to highlight the approach of "sullam al-ta'alum" and explain its impotrance in the context of studying fiqh at the higher learning instituation. Attemps and efforts at strengthening the study of fiqh should be among the main focus of muslim scholars, especially lecturers at the universities. In this regard, from the early days of Islam, Many great ulama had laid great emphasis on the approach of the so-called "sullam al-ta'allum" in studying Islamic sciences. Through the approach of "sullam al-ta'alum" various selected great works on fiqh will be introduced to the students and will become the main reference sources throughout their study.
\end{abstract}

* Pensyarah Kanan, Jabatan Fiqh \& Usul, Akademi Pengajian Islam, Univerisiti Malaya. 


\section{KEAGUNGAN ILMU SYAR'IYAH DAN ILMU FIQH MENURUT ISLAM}

Islam adalah agama yang berpaksikan kepada ilmu yang termaktub di dalam kitab al-Quran dan al-Sunnah. Segala khazanah ilmu yang dapat digali dan diistinbatkan daripada kedua-dua sumber utama tersebut diistilah sebagai 'ulum syar'iyyah.

Melalui perkembangan masa yang berlaku, bermula dari saat Nabi Muhammad SAW dibangkitkan sebagai Rasul untuk sekalian umat manusia, amalan dan ilmu yang berasaskan kepada al-Quran dan al-Sunnah mula berkembang, dipelajari, dikaji, diperhalusi dan disebarkan oleh para ilmuwan Islam yang terawal di kalangan para Sahabat Nabi SAW dan para Tabi`in.

Sejarah membuktikan bahawa para ilmuwan Islam telah memberikan sumbangan dan komitmen yang terlalu besar di dalam penyebaran ilmu-ilmu Islam di mana di antara ilmu-ilmu Syariah yang mendapat perhatian yang tersangat besar di kalangan para ulama Islam adalah ilmu fiqh. Penyebaran ilmu-ilmu Syar‘i menjadi sebegitu rancak dan, menurut pemerhatian penulis, boleh dianggap sebagai sesuatu yang amat luar biasa jika "kerancakan" ini dibandingkan dengan pertumbuhan dan perkembangan ilmu-ilmu lain di dunia ini.

Sesungguhnya hakikat yang berlaku ini bukanlah sesuatu yang pelik jika disedari bahawa Islam telah memberikan kedudukan yang teramat istimewa kepada nilai dan kedudukan apa yang diistilahkan sebagai al-'Ulum Syar 'iyyah. Sebagai misalan, di dalam menjelaskan hakikat ini, ulama tersohor Islam, Abū Zakariyā Yahyā bin Syaraf al-Nawāwì, di dalam karya tersohornya Minhāj alTạalibìn menyatakan, "......maka sesungguhnya memberikan tumpuan dan mencurahkan tenaga di dalam pencarian ilmu Syar ' $\bar{i}$ adalah di antara seutama-utama ketaatan [kepada Allah] dan seutama-utama apa yang dicurahkan kepadanya daripada detikdetik masa yang berharga [nafä 'is al-awqāt]."1

Muḥammad al-Khatīb al-Syarbīní (t.t.), Mughnì al-Muhtaj ilā Ma'rifatì Ma'ānì Alfāz. al-Minhāj, j.1, (t.t.p.) hh. 99-100. 


\section{Sekilas Pandang Mengapa Ulum Syar 'iyyah Menduduki Kedudukan Yang Teristimewa Di Dalam Islam, Yang Merentasi Kedudukan IImu-Ilmu Lain}

Di dalam menjelaskan hakikat ini penulis ingin memetik keyataan Hujjah al-Islām, Muhammad Abū Hamìd al-Ghazāli di dalam

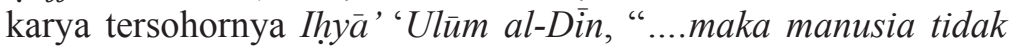
mungkin berupaya untuk sampai kepada Allah melainkan dengan [memahami dan mengamalkan] ilmu Syar' $\bar{i}$, di mana seagungagung perkara yang ingin dicapai oleh setiap anak Adam ialah kebahagiaan yang kekal abadi [di Akhirat], maka dalam konteks ini, seutama-utama perkara [afdal al-asyyā'] ialah apa jua yang merupakan "wasilah dan jalan" yang boleh membawa kepada kebahagiaan abadi tersebut. [Dalam konteks ini] tidak ada sesiapa pun yang berupaya untuk mencapai kebahagiaan abadi tersebut [yang menjadi sasaran terbesar s'etiap manusia] melainkan dengan mengetahui ilmu ini [ilmu Syar 'ī] dan beramal dengannya....."

\section{Kebijaksanaan Dan Ketelitian Para Fuqaha' Dalam Proses}

\section{Penyusunan Ilmu Fiqh: Antara al-Mabsūtāàt dan al-Mukhtasarat}

Kebijaksanaan, ketelitian dan kehebatan para ulama lampau di dalam menghasilkan karya-karya fiqh adalah sesuatu yang teramat nyata lagi terserlah bagi sesiapa yang mengkaji, meneliti dan menyelidiki karya-karya fiqh yang ditinggalkan oleh mereka. Tidak dapat dinafikan bahawa segala pendekatan penyusunan yang dilakukan oleh para ulama tersebut bertujuan untuk mempermudahkan proses pengajian ilmu fiqh itu sendiri dan karya-karya fiqh tersebut, jika diperhalusi, sememangnya bertujuan untuk memenuhi keperluan pengajian ilmu fiqh dalam setiap peringkat pengajian, iaitu dari peringkat ter-asas [permulaan] sehinggalah ke peringkat yang tertinggi [pengkhususan].

Kerana itu kita mendapati, sebagaimana yang dinyatakan sendiri oleh ulama tersohor, al-Nawāwì, karya-karya fiqh secara umumnya boleh dibahagikan kepada dua kategori utama iaitu ka-

2 Muhammad Abū Ḥamìd al-Ghazālì (t.t.), Ihyyā' 'Ulūmuddīn, j. 1. (t.t.p), h. 21. 
rya-karya yang bersifat al-Mabsūtât dan karya-karya yang bersifat al-Mukhtasarat. ${ }^{3}$

Menurut penjelasan Muḥammad al-Khatíb al-Syarbini, apa yang dimaksudkan dengan al-Mabsūtât ialah ialah karya-karya fiqh yang "......banyak lafaz-lafaznya [ungkapan-ungkapan ayatnya] dan terperinci maknanya..." manakala al-Muktașarat ialah karya-karya fiqh yang “....ringkas lafaz-lafaznya namun mendalam pengertiannya..."4.

\section{Mengapa Pengkategorian Karya-Karya Fiqh Kepada al-Mabsūtāt dan al-Mukhtașarat Amat Penting Dalam Proses Pemantapan Keilmuan Fiqh Seseorang}

Sebenarnya di dalam konteks pengajian ilmu fiqh, malah di dalam pengajian kesemua ilmu-ilmu Islam yang termasuk dalam kategori 'Ulum Syar'iyyah, kewujudan karya-karya yang bersifat al-Mukhtasarat dan al-Mabsūtāt tersebut mempunyai pengertian dan tujuan yang amat mendalam dalam konteks "pembinaan, pematangan dan pemantapan" keilmuan seseorang penuntut ilmu itu.

Jika ditelitisecarajujurdanadil,kewujudankarya-karyatersebut, dari satu segi, menyerlahkan hakikat bahawa pengajian ilmu fiqh sewajarnya ditempuhi melalui suatu proses pengembangan dan peningkatan yang tersusun rapi, yang mera'ikan pendekatan dan adab-adab disiplin ilmu tersebut sehingga memungkinkan seseorang itu mencapai tahap yang tertinggi di dalam bidang ilmu yang dipelajari.

Begitu juga dari satu segi yang lain, karya-karya yang bersifat al-Mukhtasarat tersebut, jika diteliti, bertujuan untuk menjelaskan intisari dan intipati yang terpenting [isu-isu teras fiqh] di dalam setiap bab dan permasalahan fiqh, yang wajib diketahui oleh setiap penuntut fiqh. Ini bermakna menelaah dan memahami karya alMukhtasarat bolehlah dianggap sebagai langkah permulaan [pintu masuk utama] yang perlu dilalui sebelum seseorang itu menerokai

Al-Syarbini (t.t.), op.cit., h. 101.

Ibid. 
ruang lingkup ilmu fiqh yang lebih mendalam dan terperinci, yang dapat dilihat di dalam karya-karya al-Mabsūțāt.

\section{Apakah Pendekatan Terbaik Dalam Pemantapan Pengajian Fiqh Di Institusi Pengajian Tinggi?}

Penulis amat bersetuju dan mendokong sepenuhnya pendekatan pengajian fiqh yang berasaskan kepada apa yang diistilahkan oleh para ulama dengan ungkapan "sullam al-ta'allum". Ungkapan ini bolehlah diterjemahkan secara umumnya sebagai "pendakian, secara berperingkat, tangga-tangga pengajian dan pembelajaran". ${ }^{5}$ Pada hakikatnya dan tiada sesiapa pun yang dapat menafikannya, proses pemantapan ilmu fiqh di kalangan para penuntut ilmu bukanlah suatu usaha yang boleh dicapai dalam masa yang singkat. Namun keterbatasan masa dan kesingkatan tempoh pengajian yang wujud di universiti pada hari ini [sekitar empat tahun] tidak sewajarnya mengenepikan sama sekali pendekatan sullam al-ta'alum ini, yang merupakan metod pengajian fiqh ulama-ulama terbilang lagi tersohor yang lampau. Malah, jika diperhatikan, kewujudan karya-karya fiqh yang bersifat al-Mukhtașarat dan al-Mabsūțāt memperkukuhkan lagi kepentingan, keperluan dan kerelevanan pendekatan sullam al-ta'alum ini di dalam pengajian fiqh.

\section{Ciri-Ciri Utama Pendekatan Pengajian "Sullam al-Ta'allum" Dalam Konteks Pengajian Fiqh Syafi'i Di Institusi Pengajian Tinggi : Satu Pandangan Dan Cadangan}

Terlebih dahulu ingin dinyatakan di sini bahawa pengajian ilmu-ilmu Syar'i, dan khususnya ilmu fiqh, menurut "pendekatan pengajian peringkat" iaitu bermula dalam ruang lingkupnya yang asas, kemudian disusuli ke tahap yang lebih luas dan akhirnya ke tahap yang paling terperinci lagi mendalam bukanlah suatu pendekatan pembelajaran yang diada-adakan tanpa dokongan dan penjelasan para ulama Islam yang muktabar.

Di dalam kitab tersohor Ihyā' Ulūmuddīn, Imam Abū Hamìd al-Ghazāli menjelaskan bahawa secara umumnya setiap disiplin

Abdul Aziz Abdul Fattah (t.t.), Barnāmij 'Amalī li al-Mutafaqqihin, (t.t.p.) hh. 38-39. 
ilmu daripada 'ulüm Syar'ïyyah boleh dibahagikan kepada tiga peringkat pengajian iaitu 1] al-Iqtiṣār, 2] al-Iqtiṣād dan yang tertingginya 3] al-Istiqșā'. Al-Iqtișār, jelas beliau, merujuk kepada peringkat pengajian yang asas yang perlu dipelajari oleh setiap Muslim, dan sekiranya ruang umur dan masa mengizinkannya maka bolehlah dia berpindah ke peringkat al-iqtisād yang merupakan peringkat pengajian di tahap pertengahan dan sederhana. Dan kemudian sekiranya ruang masa dan umur mengizinkan barulah seseorang itu sewajarnya meneroka ilmu-ilmu Islam pada peringkat al-istiqșa , iaitu di tahap tertinggi, terperinci dan bersifat khusus. ${ }^{6}$ Penjelasan Imām al-Ghazali di sini, menurut pemerhatian penulis, jelas memperlihatkan bahawa pengajian ilmu-ilmu Syar'i sememangnya dan sewajarnya berasaskan kepada tahap-tahap perkembangan pengajian yang perlu dilalui oleh seorang penuntut dan inilah prinsip utama yang ditekankan oleh para ulama di dalam pendekatan sullam al-ta'alum.

\section{Pendedahan Awal terhadap karya-karya mazhab Syafi'i yang bersifat al-Mabsūțāt dan al-Mukhtașarat}

Adalah suatu hakikat yang tidak dapat dinafikan bahawa terdapat banyak karya-karya yang dihasilkan oleh para ulama mazhab Syafi'i yang dapat dirangkumkan samada dalam kategori al-Mukhtașarat atau dalam kategori al-Mabsūtạt. Antara karyakarya muktabar yang dapat dinyatakan di sini [sebagai misalan] ialah seperti kitab Minhāj al-Ṭalibīn karya Imām al-Nawāwí, kitab al-Wajīz fí al-Mazhab dan al-Wasitfí al-Mazhab karya Imām al-Ghazālì, kitab al-Muhadhdhab karya Abū Isḥāq al-Syïāzi dan kitab 'Umdah al-Sālik karya Ibn al-Naqīb.

Sebenarnya pendedahan awal terhadap karya-karya utama tersebut adalah teramat penting bagi para pelajar. Ianya sudah pasti akan dapat dijadikan sebagai "pemandu-arah awal" di dalam mengenali karya-karya muktabar di dalam pengajian fiqh di masamasa akan datang. Malah menurut penulis, para pelajar seharusnya menghafal nama karya-karya utama fiqh mazhab Syafi' $i$.

Antara kepincangan yang masih dapat dilihat di kalangan para pelajar pengajian Islam, menurut pengalaman penulis,

Al-Ghazali (t.t.), op.cit., h. 55. 
ialah kejahilan mereka mengenai kewujudan karya-karya yang dinyatakan itu. Ini bermakna para pelajar hampir tidak berkemampuan untuk menyatakan nama karya-karya utama di dalam mazhab Syafi'i dan kelemahan ini sudah pasti berkaitan dengan pendekatan kita di dalam menyampaikan pengajian fiqh Syafi'i kepada para pelajar.

\section{Pemilihan yang teliti satu karya Mukhtasar [atau yang ditahap al-Iqtiṣa' menurut bahasa yang digunakan oleh Imam al-Ghazāli] yang perlu dipelajari dalam tahun pertama dan kedua}

Peringkat kedua ini merupakan peringkat yang teramat penting dalam proses pembinaan dan pemantapan pengajian fiqh Syafi‘ $i$ di kalangan para pelajar. Untuk melahirkan para faqih di masa akan datang, para pelajar sewajarnya diasuh, bukan sahaja dengan memperkenalkan nama-nama karya-karya muktabar fiqh Syafi' $i$ tersebut, tetapi juga dengan membaca, melihat, meneliti dan mengkaji isu kandungan salah satu daripada karya-karya agung tersebut. Pada hakikat dan realitinya, inilah pendekatan pembelajaran yang ditempoh oleh para ulama tersohor yang lampau.

Dalam konteks pengajian fiqh Syafi'i di Malaysia, mungkin antara karya agung yang boleh penulis cadangkan di sini ialah kitab al-Muhadhdhab karya Imām al-Syirāzí. Dalam konteks ini juga, ekoran daripada keterbatasan tempoh pengajian yang wujud, seseorang pensyarah mungkin dapat memilih baba-bab tertentu ataupun fasal-fasal tertentu yang perlu ditelaah dan diperhalusi bersama para pelajar dalam tempoh dua tahun tersebut.

\section{Pemilihan yang teliti satu karya al-Mabsūtāt [atau} yang ditahap al-istiqșār menurut bahasa yang digunakan oleh Imam al-Ghazālī] yang perlu dipelajari dalam tahun yang ketiga dan keempat

Sebagai mana yang dinyatakan di atas, dalam proses pembinaan dan pemantapan keilmuan fiqh para pelajar, mereka wajib, bukan sahaja didedahkan dengan nama karya-karya tersohor mazhab 
Syafi' $i$, tetapi juga didedahkan melalui pendekatan mempelajari, menyelidiki dan mengkaji karya-karya tersebut dalam ruang lingkup masa dan tempoh pengajian yang wujud untuk mereka. Dalam konteks karya al-Mabsūțât di sini, mungkin antara karya agung yang cukup sesuai dicadangkan di sini ialah seperti kitab alMajmū' Syarh al-Muhadhdhab karya Imām al-Nawāwì ataupun kitab al-Mughni karya Imām Ibn Qudāmah al-Maqdīìi.

Sebenarnya kedua-dua karya yang penulis nyatakan itu lebih merupakan karya fiqh muktabar yang bersifat al-fiqhal-muqārin. Di sinilah, pada hemat penulis, terletaknya kelebihan dan keunggulan karya-karya tersohor tersebut kerana para pelajar bukan sahaja dapat mempelajari fiqh mazhab Syafi'i, malah merangkumi hukum-hakam fiqh di dalam mazhab yang lain. Sesungguhnya pendekatan seumpama ini merupakan suatu proses pembelajaran yang amat penting dalam pembinaan dan pemantapan malakah fiqhiyyah di dalam diri para pelajar.

\section{Mengapa Pemilihan Beserta Penelaahan "Karya- Karya Fiqh Tersohor" Suatu Keperluan Besar Dalam Pemantapan Pengajian Fiqh Syafi'i}

Suatu perkara yang perlu disedari dan diinsafi oleh kita ialah karya-karya fiqh tersohor mazhab Syafi ${ }^{6} i,{ }^{7}$ seperti yang dinyatakan di atas, yang kebiasaannya diistilahkan oleh para ilmuwan Islam sebagai karya-karya muktabar atau karya turāth merupakan karyakarya fiqh yang mempunyai nilai-nilai ilmiah dan akademik yang tinggi dalam konteks penulisan ilmu fiqh itu sendiri.

Pada pendapat penulis, mungkin secara ringkasnya antara kepentingan, kelebihan dan keutamaan yang bakal diperolehi oleh para pelajar apabila mereka menelaah dan mengkaji karya-karya tersohor tersebut :

1. Mereka akan dapat mempelajari istilah-istilah dan ungkapanungkapan fiqh [muștalahăt fiqhìyyah] yang kerap digunapakai di dalam karya-karya tersohor dalam konteksnya yang sebenar, seperti ungkapan awjūh, fí al-așaḥi $\bar{i}$ al-așaḥhu almanșūṣ, al-aqwāl, al-awjūh, al-masyhūr, al-aṣhāb, al-naṣ,

Dan juga mazhab-mazhab lain yang muktabar 
al-șhịh dan lain-lain. Sesuatu yang tidak dapat dinafikan ialah setiap ungkapan-ungkapan fiqh yang dinyatakan di atas mempunyai maksudnya yang tersendiri, yang perlu difahami apabila membaca karya-karya muktabar fiqh. Bagaimana mungkin para pelajar akan dapat memahami istilah-istilah tersebut seandainya mereka tidak didedahkan di peringkat pengajian tinggi sedangkan rujukan-rujukan karya fiqh muktabar tersebut merupakan "primary source" [rujukan utama] di dalam penulisan-penulisan ilmiah peringkat sarjana dan doktor falsafah pada hari ini. Sesungguhnya inilah suatu persoalan yang tidak boleh dipandang enteng dan remeh seandainya kita benar-benar ikhlas ingin memantapkan "kualiti" pengajian fiqh di peringkat universiti.

2. Mereka akan dapat mempelajari serta mengembangkan pelbagai perbendaharaan kata Arab yang mempunyai perkaitan yang langsung dengan perbahasan-perbahasan fiqh. Sebagai misalan, apabila para pelajar membaca bab yang berkaitan dengan pakaian yang harus dipakai oleh seorang lelaki maka mereka akan menemui lafaz-lafaz seperti al-dibāj, al-harìi, al-ibrisam, al-khas ${ }^{8}$ dan seumpamanya. Misalan yang lain, di dalam mempelajari bab waktu-waktu sembahyang fardu mereka akan menemui lafaz-lafaz seperti qurs al-syams, al-saharā, al-'umran, qulalu al-jibal, maghỉb al-syafaq dan sebagainya. ${ }^{9}$ Ringkasnya, setiap bab daripada bab-bab ilmu fiqh memiliki pelbagai perbendaharaan kata Arab yang perlu dipelajari dan difahami oleh para pelajar. Justeru, pengkajian karya-karya turāth merupakan suatu proses pembelajaran fiqh yang tidak dapat dikesampingkan sama sekali.

Walaupun kita kini hidup di tahun masihi 2007 dan karyakarya tersebut mungkin telah ditulis sekitar 700 atau 800 tahun yang lalu namun apakah mungkin kita boleh mendakwa bahawa lafaz-lafaz Arab yang terpakai di dalam khazanahkhazanah berharga tersebut sudah lapuk ditelan zaman dan tidak relevan lagi dalam konteks penggunaan bahasa zaman ini? Apakah mungkin seseorang pensyarah itu akan dapat menghasilkan sebuah tesis $\mathrm{PhD}$ yang sah, berkualiti lagi

Abū Isḥāq al-Syīrāzì (t.t.), al-Muhadhdhab, j. 1. (t.t.p.) h. 353.

Al-Nawāwì (t.t.), Rawdah al-Tạlibīin, j. 1. (t.t.p.) h. 290. 
bermutu sekiranya tugasan "literature review"nya [pengkajiannya dan pemerhatiannya terhadap kajian-kajian yang lalu] tidak dapat dilaksanakan dengan baik?

3. Mereka akan dapat melihat dan mempelajari pelbagai hadishadis Nabi SAW yang berkaitan secara langsung dengan isu-isu hukum-hakam fiqh. Ini adalah antara keistimewaan besar apabila membaca karya-karya yang termasuk dalam kategori al-Mabsūțât seperti kitab al-Majmū ${ }^{6}$ karya al-Nawāwì. Sebagai misalan, kitab al-Muhadhdhab karya al-Syirāzi adalah antara kitab yang sentiasa menyatakan dalil-dalil hukum yang menjadi sandaran di dalam persoalanpersoalan fiqh mazhab Syafi'i. Dengan mengkaji dan menelaah kitab tersebut secara tidak langsung para pelajar, bukan sahaja akan dapat mengenal-pasti dan mungkin menghafal pelbagai hadis-hadis hukum, malah akan dapat juga meneliti dan mengkaji bentuk dan pendekatan al-istidlāl [kaedah-kaedah berhujah berdasarkan naș] yang dikemukakan oleh para ulama dalam penetapan pelbagai hukum-hakam fiqh. Latihan akademik seumpama ini sudah pasti akan dapat memantapkan kematangan diri para pelajar dalam memahami jalan-jalan penghujahan yang digunapakai dalam pembinaan ilmu fiqh dan, secara tidak langsung juga, boleh mempertingkatkan kemahiran untuk berijtihad.

4. Mereka akan dapat mempelajari pendekatan "penghujahan secara akal" [al-adillah al-'aqliyyah] yang kerap digunakan oleh para ulama di dalam memperkukuhkan pelbagai hukum-hakam fiqh. Adalah sesuatu yang nyata bahawa penggunaan hujah dan dalihan secara akal dan logik ini dapat dilihat dengan banyak di dalam perbahasan-perbahasan fiqh, antaranya di dalam kitab al-Mughnī karya Imām Ibn Qudāmah. Tidak dapat dinafikan bahawa pendedahanpendedahan akademik seumpama inilah adalah terlalu penting dalam konteks pembelajaran ilmu fiqh. Secara tidak langsung pembelajaran seperti ini pastinya akan dapat mempertingkatkan malakah fiqhiyyah di dalam diri para pelajar pengajian fiqh.

5. Dengan memperhalusi dan menerokai karya-karya fiqh yang muktabar, para pelajar akan dapat mengenal-pasti isu-isu fiqh utama yang tidak wajar dikesampingkan yang 
berkaitan dengan bab-bab hukum-hakam fiqh yang mereka sedang pelajari. Jika kita meneliti karya-karya fiqh yang muktabar kita akan mendapati bagaimana para fuqaha sering membezakan antara satu isu utama dengan satu isu yang lain, di dalam bab yang sama, dengan menggunakan ungkapan seperti "far" un" ataupun "fașlun". Tidak dapat dinafikan bahawa apa yang dilakukan oleh para fuqaha' di sini adalah bertujuan untuk menjelaskan serta mengenengahkan isu-isu utama yang berkaitan dengan bab yang sedang diperbincangkan. Sebenarnya penelitian terhadap isu-isu utama yang dipisahkan dengan ungkapan "fașlun" adalah terlalu penting diteliti. Ini adalah bagi memungkinkan setiap pembaca karya tersebut tidak akan "terlepas pandang" terhadap permasalahan-permasalah fiqh utama yang berkaitan dengan bab yang sedang dibaca.

\section{RUMUSAN}

Proses pembinaan dan pemantapan pengajian fiqh Syafi ${ }^{\circ} i \mathrm{di}$ peringkat institusi pengajian tinggi seharusnya bermula melalui suatu pendekatan pengajian fiqh yang diungkapkan sebagai sullam al-ta'allum, namun pendekatan ini sewajarnya disesuaikan dengan ruang masa dan tempoh pengajian yang wujud di kalangan para pelajar di Institusi Pengajian Tinggi. Menurut penulis, prinsipprinsip utama dalam pemantapan dan pengukuhan pengajian fiqh seharusnya melibatkan penelitian yang menyeluruh terhadap karyakarya tersohor fiqh mazhab Syafi'i dan disusuli dengan pemilihan karya-karya tertentu, yang dilihat paling sesuai dan terbaik, yang bakal dijadikan teks pengajian dan kajian di kalangan para penuntut ilmu. Pendekatan pengajian seumpama ini adalah terlalu penting khususnya bagi mempastikan kesinambungan kewujudan ilmuwan-ilmuwan Islam dan para fuqaha tanah air yang mampu memahami serta menerokai permasalahan-permasalahan fiqh mazhab Syafi'i melalui sumber-sumbernya yang muktamad lagi berautoriti. Inilah di antara usaha-usaha utama yang diperlukan bagi menjamin keutuhan dan kesinambungan mazhab Syafi‘ $i$ di Malaysia. 
Jurnal Fiqh: No. 4 (2007) 173-184 